\title{
CCAAT/enhancer binding protein $\beta$ is required for satellite cell self-renewal
}

\author{
Neena Lala-Tabbert ${ }^{1}$, Hamood AlSudais ${ }^{1}$, François Marchildon ${ }^{1}$, Dechen $\mathrm{Fu}^{2}$ and Nadine Wiper-Bergeron ${ }^{2^{*}}$ (D
}

\begin{abstract}
Background: Postnatal growth and repair of skeletal muscle relies upon a population of quiescent muscle precursor cells, called satellite cells that can be activated to proliferate and differentiate into new myofibers, as well as self-renew to replenish the satellite cell population. The balance between differentiation and self-renewal is critical to maintain muscle tissue homeostasis, and alterations in this equilibrium can lead to chronic muscle degeneration. The transcription factor CCAAT/enhancer binding protein beta (C/EBP $\beta$ ) is expressed in Pax $7^{+}$satellite cells of healthy muscle and is downregulated during myoblast differentiation. Persistent expression of C/EBP $\beta$ upregulates Pax7, inhibits MyoD, and blocks myogenic differentiation.
\end{abstract}

Methods: Using genetic tools to conditionally abrogate C/EBP $\beta$ expression in Pax $7^{+}$cells, we examined the role of C/EBP $\beta$ in self-renewal of satellite cells during muscle regeneration.

Results: We find that loss of C/EBP $\beta$ leads to precocious differentiation at the expense of self-renewal in primary myoblast and myofiber cultures. After a single muscle injury, C/EBP $\beta$-deficient satellite cells fail to self-renew resulting in a reduction of satellite cells available for future rounds of regeneration. After a second round of injury, muscle regeneration is impaired in C/EBP $\beta$ conditional knockout mice compared to wild-type control mice. We find that C/EBP $\beta$ can regulate Notch2 expression and that restoration of Notch activity in myoblasts lacking C/EBP $\beta$ prevents precocious differentiation.

Conclusions: These findings demonstrate that C/EBP $\beta$ is a novel regulator of satellite cell self-renewal during muscle regeneration acting at least in part through Notch2.

Keywords: C/EBP $\beta$, Satellite cell, Self-renewal, Pax7, MyoD, Notch

\section{Background}

Skeletal muscle has a remarkable capacity to regenerate after injury, which depends on the presence of muscle progenitor cells, called satellite cells (SC) $[1,2]$. In adult muscle, satellite cells make up $2-7 \%$ of all myonuclei and express the paired-box transcription factor Pax7 [3-6]. After myofiber damage, SCs quickly upregulate the myogenic regulatory factor MyoD and re-enter the cell cycle to give rise to a population of transient-amplifying cells [7-9]. Subsequently, they downregulate Pax7, irreversibly withdraw from the cell cycle, upregulate myogenin expression, commit to terminal differentiation, and fuse to repair damaged fibers or to create new ones $[8,10-12]$. While a large majority of myoblasts will differentiate into myocytes, a small percentage of myoblasts

\footnotetext{
* Correspondence: Nadine.WiperBergeron@uottawa.ca

${ }^{2}$ Department of Cellular and Molecular Medicine, Faculty of Medicine,

University of Ottawa, 451 Smyth Road, Ottawa, Ontario K1H 8M5, Canada

Full list of author information is available at the end of the article
}

escape differentiation by maintaining Pax7 expression, downregulating MyoD expression, and returning to mitotic quiescence $[1,13]$. As such, the expression of Pax7 and MyoD allows for classification of SCs as self-renewing $\left(\mathrm{Pax}^{+} / \mathrm{MyoD}^{-}\right)$, proliferating $\left(\mathrm{Pax}^{+} / \mathrm{MyoD}^{+}\right)$, or differentiating $\left(\mathrm{Pax}^{-} / \mathrm{MyoD}^{+}\right)[11,13-15]$. Self-renewal is important for maintaining the precursor pool and transplantation of $\mathrm{SCs}$, or single muscle fibers can contribute to the repair of hundreds of new muscle fibers $[1,16]$ and replenishment of the stem cell niche [17].

CCAAT/enhancer binding proteins (C/EBPs) are a family of transcription factors that regulate cellular growth and differentiation, metabolism, and inflammation [18]. In skeletal muscle, C/EBP $\beta$ expression is localized to $\mathrm{Pax}^{+} \mathrm{SCs}$ of healthy muscle and is rapidly downregulated upon induction to differentiate $[19,20]$. In vivo, loss of C/EBP $\beta$ expression in SCs resulted in larger muscle fiber cross-sectional area, fewer fibers, and 
improved repair after a single acute muscle injury $[19,20]$. When overexpressed in the murine myoblast cell line $\mathrm{C} 2 \mathrm{C} 12$ or in primary myoblasts, C/EBP $\beta$ reduced MyoD and other myogenic protein levels during differentiation, in addition to reducing myoblast fusion. C/EBP $\beta$ also increased Pax7 protein expression suggesting that $\mathrm{C} / \mathrm{EBP} \beta$ acts to maintain myogenic progenitors in an undifferentiated state $[19,21]$.

In this study, we examined the role of C/EBP $\beta$ in SC self-renewal using conditional knockout mice $\left(\mathrm{Cebpb}^{f l}\right.$ ${ }^{f l} \operatorname{Pax} 7^{\mathrm{CreER} /+}$ ) in which C/EBP $\beta$ is knocked down in $\operatorname{Pax} 7^{+}$ cells following activation of the CreER recombinase with tamoxifen [19-23]. Loss of C/EBP $\beta$ in SCs results in precocious differentiation at the expense of self-renewal in both primary myoblasts and myofiber cultures. Further, C/EBP $\beta$-deficient SCs are unable to self-renew after muscle injury leading to a reduction in the SC pool such that it cannot efficiently support muscle regeneration after a second round of injury. Mechanistic studies revealed that $C / E B P \beta$ can regulate Notch2 expression and selfrenewal can be rescued in $\mathrm{C} / \mathrm{EBP} \beta$-deficient myoblasts by overexpression of the Notch intracellular domain (NICD) indicating that $\mathrm{C} / \mathrm{EBP} \beta$ acts, at least in part, by regulating Notch signaling. Taken together, these results establish C/ $\mathrm{EBP} \beta$ as a novel regulator of SC homeostasis.

\section{Methods}

\section{Mice and animal care}

All animal work was performed in accordance with the guidelines set out by the Canadian Council on Animal Care and was approved by the University of Ottawa Animal Care Committee. A mouse bearing a C/EBP $\beta$-floxed allele $(\mathrm{C} /$ $\left.\mathrm{EBP}^{\mathrm{fl} / \mathrm{fl}}\right)$ [22] was crossed with mice bearing the Pax7$\mathrm{CreER}^{\mathrm{tm}}$ allele [23] to generate $\mathrm{C} / \mathrm{EBP}^{\mathrm{t} / / \mathrm{l}} \mathrm{Pax}^{+/+}$(wildtype, WT) and conditional null C/EBP $\beta^{-/-} \mathrm{Pax}^{\mathrm{CreER}-/+}(\mathrm{C} /$ $\mathrm{EBP}^{-/-}$) animals as previously described [19]. All animals were housed in a controlled facility $\left(22^{\circ} \mathrm{C}\right.$ with $30 \%$ relative humidity on a 12-h light/dark cycle) and provided with food and water ad libitum. In vivo induction of CreER ${ }^{\mathrm{tm}}$ activity, for myofiber and muscle injury experiments, was accomplished by performing daily intraperitoneal injections of $3 \mathrm{mg} / 40 \mathrm{~g}$ body weight of tamoxifen (dissolved in corn oil; Sigma-Aldrich) for 5 days.

For single $\mathrm{BaCl}_{2}$ injury, the mice were anesthetized with isoflurane and the hind limbs were shaved before the procedure. The $\mathrm{C} / \mathrm{EBP} \beta^{\mathrm{fl} / \mathrm{fl}}$ and $\mathrm{C} / \mathrm{EBP} \beta^{-/-} \mathrm{Pax} 7^{\mathrm{C}-}$ reER- $/+$ mice aged 8-10 weeks were injected with $50 \mu \mathrm{l}$ of $1.2 \% \mathrm{BaCl}_{2}$ in PBS into the left tibialis anterior (TA) muscle. The mice were sacrificed 4,7 , and 42 days post injury (dpi) and the TA was collected, embedded in Tissue-Tek OCT compound, flash frozen in isopentane cooled by liquid nitrogen, and sectioned $(8-\mu \mathrm{m}$ thick) for immunofluorescence. For double $\mathrm{BaCl}_{2}$ injury, the mice were allowed to recover from a $\mathrm{BaCl}_{2}$ injury for 21 days before a second injury to the same TA. The mice were sacrificed 7 and 21 days after the second injury.

\section{Primary and $\mathrm{C} 2 \mathrm{C} 12$ myoblast culture}

Primary myoblasts were isolated as described previously [24]. Briefly, the hind limb muscles of adult (6 to 8 weeks of age) mice were dissected and digested with collagenase/dispase (Roche). After digestion, the muscle slurry was filtered through a $70-\mu \mathrm{M}$ cell strainer to remove undigested muscle. The cells were washed with serumfree media and then enriched for myoblasts by magneticactivated cell sorting (MACS) [24]. The primary myoblasts were grown on matrigel-coated plates in growth media (GM: DMEM (Wisent) containing 20\% FBS, 10\% HS (Invitrogen) with penicillin and streptomycin (Wisent)) supplemented with $10 \mathrm{ng} / \mathrm{ml}$ basic fibroblast growth factor (bFGF) and $2 \mathrm{ng} / \mathrm{ml}$ human growth factor (HGF) (Peprotech). Differentiation was induced by changing the media of confluent cultures to differentiation media (DM: DMEM containing 2\% FBS and 10\% HS) for $48 \mathrm{~h}$. To induce $\mathrm{CreER}^{\mathrm{tm}}$ activity in culture, primary myoblasts from wild-type and conditional knockout animals were treated with $4-\mathrm{OH}$ tamoxifen $(2 \mu \mathrm{M}$ dissolved in $100 \%$ ethanol; Sigma-Aldrich) for $48 \mathrm{~h}$. To induce Notch activity, primary myoblasts were retrovirally transduced with empty vector (pLPCX) to express the Notch1 intracellular domain (pLPCX-NICD) and maintained in growth medium.

$\mathrm{C} 2 \mathrm{C} 12$ murine myoblasts were retrovirally transduced with empty vector (pLXSN) or to express C/EBP $\beta$ (pLXSN-C/EBP $\beta$ ), selected based on G418 resistance, and maintained in growth medium (DMEM with 10\% FBS).

\section{Western analysis}

Whole-cell extracts from primary myoblasts were resolved on a $12 \%$ SDS-PAGE gel, transferred to a PVDF membrane, and probed with specific antibodies: C/EBP $\beta$ (E299; Abcam), Notch intracellular domain 1 (NICD1; EMD Millipore), and cyclophilin B (Abcam). Chemiluminescence was detected with the ChemiDocTM MP System (Bio-Rad Laboratories).

\section{Limited trypsinization}

Myotubes were separated from reserve cells in differentiated WT and $\mathrm{C} / \mathrm{EBP}^{-1-}$ myoblast cultures as previously described [25]. Briefly, myoblasts were plated on $10-\mathrm{cm}$ culture plates, cultured in GM until confluent, and then induced to differentiate in DM for $48 \mathrm{~h}$. Following differentiation, myotubes were removed from reserve cells by limited trypsinization ( $0.15 \%$ trypsin for $5 \mathrm{~min})$. Reserve cells, which remained attached to the culture plate, were removed with $0.25 \%$ trypsin. Reserve cells were counted and then re-plated to be induced for differentiation. 
Isolation and culture of single EDL myofibers

Myofibers were isolated from the extensor digitorum longus (EDL) muscle as described previously [26]. Briefly, the EDLs were removed from adult (6-8 weeks of age) mice and digested with collagenase type I $(2 \mathrm{mg} / \mathrm{ml}$ in DMEM; Sigma-Aldrich). The muscles were transferred to horse serum-coated plates, and myofibers were separated by trituration using heat-polished glass Pasteur pipettes. Fibers were incubated for $72 \mathrm{~h}$ in DMEM supplemented with $15 \%$ FBS and $2 \%$ chick embryo extract at $37{ }^{\circ} \mathrm{C}, 5 \% \mathrm{CO}_{2}$.

\section{Immunofluorescence}

Myofibers were fixed in $4 \%$ paraformaldehyde (PFA) in PBS and $1 \%$ glycine and blocked in PBS containing $0.2 \%$ Triton X-100 (BioShop), 2\% BSA, 5\% goat serum (Cedarlane), and 1\% azide. Myoblasts were fixed in 2\% PFA in PBS and blocked in PBS containing $0.3 \%$ Triton X-100 and 10\% goat serum. Cryosections were thawed at room temperature, fixed in $4 \%$ PFA, and processed for antigen retrieval in citrate buffer at $95{ }^{\circ} \mathrm{C}$ for $20 \mathrm{~min}$. The sections were permeabilized with PBS containing $0.5 \%$ Triton X-100 and blocked in PBS containing $0.1 \%$ Triton X-100 and 5\% donkey serum (Cedarlane) prior to incubation with primary antibody overnight at $4{ }^{\circ} \mathrm{C}$. The cells were washed with PBS and incubated in biotin antimouse (when indicated) or secondary antibodies conjugated to a fluorescent dye (Cy3, Alexa 488, or Alexa Flour 647; all from Jackson ImmunoResearch). Nuclei were counterstained with DAPI $(0.5 \mu \mathrm{g} / \mathrm{ml})$. The primary antibodies used were as follows: Pax7-c (DSHB), MYH (H-300; Santa Cruz), MyoD (C-20; Santa Cruz), myogenin (M-225; Santa Cruz), C/EBP 3 (E299; Abcam), and laminin (AL-4; Millipore).

\section{Image acquisition}

Digital images of the stained myoblasts, myofibers, and muscle sections were acquired at room temperature using a microscope (Leica DM 3000B), Infinity-3 camera (Lumenera), and Infinity Capture imaging software (Lumenera). The images were composed and edited in paint.net.

\section{Chromatin immunoprecipitation}

C2C12 myoblasts were crosslinked for $30 \mathrm{~min}$ at room temperature with $1 \%$ formaldehyde and sonicated with Diagenode bioruptor ${ }^{\oplus}$. Chromatin immunoprecipitation (ChIP) analysis was performed as described [27] using antibodies against $\mathrm{C} / \mathrm{EBP} \beta(\mathrm{C}-19$; Santa Cruz) or rabbit IgG as negative control. Protein G conjugated Dynabeads (Invitrogen) were used to precipitate immunoconjugates, and DNA fragments were purified using the QIAquick PCR purification kit (Qiagen). A standard curve was generated using input DNA for each immunoprecipitate, and quantification was determined as the percentage of enrichment relative to $10 \%$ input for each condition. Primer sequences for qPCR amplification are as follows: Notch2 R1 (-19 kb; chr3:97,797,949-97,798,354) F: TGAGGAAG TTGACAGGGAGC， R: GTGTCCAGGGCAACTTGG AA; Notch2 R2 (+11 kb; chr3:97,828,475-97,828,573) F: GGAAGCGATCGGTGTTGTTG, R: AAAAGCAGTGG GGCGTCTTA; Notch2 R3 (+14 kb; chr3:97,831,399-9 7,831,590) F: TAGGAAGGATGTGGGGAGGG, R: ATCT GACACAGCAGCTTCCC; and Notch2 R4 (+43 kb; chr3:97,860,912-97,861,087) F: CTTCGTCCCTCAACC TCCTG, R: AATAGGGCCGTGGCAGAAAA.

\section{Statistical analysis}

Statistical analysis was performed using GraphPad Prism software (GraphPad Software, La Jolla, CA, USA). A student's $t$ test was used when comparing a single experimental condition to the control condition. A oneway ANOVA was performed when comparing three or more experimental conditions. A Tukey's post hoc test was used when the ANOVA was significant. The cutoff for significance was $p<0.05$. All experiments are representative of a minimum of three biological replicates, and data is presented as mean \pm standard error mean (SEM).

\section{Results \\ C/EBP $\beta$-deficient satellite cells display increased differentiation}

To investigate the functional consequences of disrupting $\mathrm{C} / \mathrm{EBP} \beta$ expression in SCs, we isolated SCs from conditional knockout mice $\left(\mathrm{Cebp} b^{f l / f l} \mathrm{Pax} 7^{\mathrm{CreER} /+}\right)$ in which $\mathrm{C} / \mathrm{EBP} \beta$ expression is abrogated in $\mathrm{Pax}^{+}$cells following activation of the CreER recombinase with tamoxifen. SC-derived myoblasts (Cebpb ${ }^{f l / f l} \mathrm{Pax}^{+/+}$(WT) and $\mathrm{C} / \mathrm{EBP}^{-/-}$) were cultured in high serum (GM) for $24 \mathrm{~h}$, and excision was confirmed by RT-qPCR, with Cebpb expression reduced to $\sim 10 \%$ of controls (Fig. 1a). In C/EBP $\beta^{-/-}$cells, Pax7 expression was significantly reduced by approximately $50 \%$ as compared to the WT controls, while Myod1 and Myog expression were unaffected (Fig. 1b). As $C / E B P \beta$ is a known regulator of $\operatorname{Pax} 7$ and MyoD protein expression, the proportion of self-renewing $\left(\operatorname{Pax} 7^{+} / \mathrm{MyoD}^{-}\right)$, proliferating $\left(\mathrm{Pax}^{+} / \mathrm{MyoD}^{+}\right)$, and differentiating $\left(\mathrm{Pax} 7^{-} / \mathrm{MyoD}^{+}\right)$ cells was assessed in $\mathrm{WT}$ and $\mathrm{C} / \mathrm{EBP} \beta^{-/-}$myoblasts in growth medium by immunostaining (Fig. 1c) [19]. The percentage of $\mathrm{Pax}^{+} / \mathrm{MyoD}^{-}$(self-renewing) cells was decreased in $\mathrm{C} / \mathrm{EBP} \beta^{-/-}$myoblasts compared to WT myoblasts (2.9 vs. 5.2\%) with a concomitant increase in Pax7 $^{-} / \mathrm{MyoD}^{+}$differentiating cells (16.2 vs. $\left.8.8 \%\right)$ (Fig. 1d, e). There was no significant change in the population of $\mathrm{Pax}^{+} / \mathrm{MyoD}^{+}$proliferating cells between $\mathrm{C} / \mathrm{EBP} \beta^{-/-}$myoblasts and WT myoblasts in GM (Fig. 1f). 


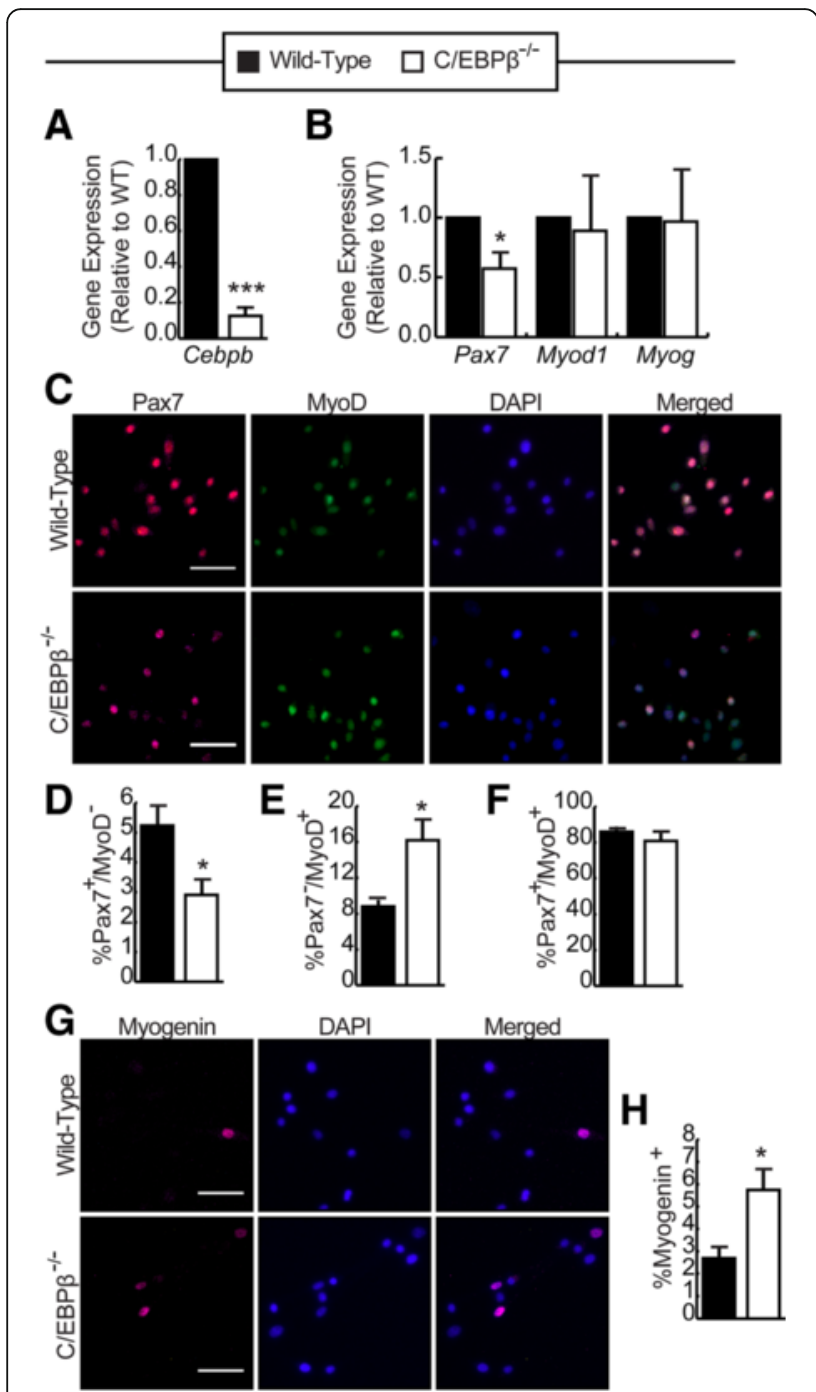

Fig. 1 Loss of C/EBP $\beta$ reduces the proportion of Pax $7^{+}$cells in myogenic cultures. a RT-qPCR analysis of Cebpb expression in primary myoblasts isolated from $\mathrm{C} / \mathrm{EBP} \beta^{\mathrm{fl} / f l} \mathrm{Pax} 7^{+/+}$(wild-type) and conditional null $\mathrm{C} / \mathrm{EBP}^{-/-} \mathrm{Pax} 7^{\mathrm{CreER}-/+}\left(\mathrm{C} / \mathrm{EBP}^{-/-}\right)$subjected to in vitro $4^{\prime} \mathrm{OH}-\mathrm{TAM}$ treatment and cultured in growth medium (GM) $(n=5)$. b RT-qPCR analysis of Pax7, Myod1, and Myog expression in primary myoblasts isolated and cultured as in $\mathbf{a}(n=5)$. c Representative pictures of myoblasts cultured under growth conditions for $24 \mathrm{~h}$ stained for Pax7 (red) and MyoD (green). Nuclei were counterstained with DAPI (blue). Scale bar, $50 \mu \mathrm{m}$. Percentage of $\mathbf{d}$ self-renewing ( $\mathrm{Pax} 7^{+} / \mathrm{MyoD}^{-}$), e differentiating $\left(\mathrm{Pax}^{-} / \mathrm{MyoD}^{+}\right)$, and $\mathbf{f}$ proliferating $\left(\mathrm{Pax} 7^{+} / \mathrm{MyoD}^{+}\right) \mathrm{WT}$ (black bars) and $\mathrm{C} / \mathrm{EBP}^{-/-}$(white bars) myoblasts cultured as in $\mathbf{a}$ as determined by immunocytochemistry $(n=4)$. $\mathbf{g}$ Representative pictures of cells cultured as in a and immunostained for myogenin (red). The nuclei were counterstained with DAPI (blue). Scale bar, $50 \mathbf{~ u m}$. h Percentage of myogenin ${ }^{+}$cells relative to total nuclei $(n=4)$. For all panels, data is represented as mean \pm SEM, ${ }^{*} p<0.05,{ }^{* * *} p<0.001$

Given the larger population of $\mathrm{Pax} 7^{-} / \mathrm{MyoD}^{+}$cells in $\mathrm{C} / \mathrm{EBP}^{-/-}$cultures, we assessed myogenin expression by immunostaining. While no significant differences were observed in mRNA expression over the population
(Fig. 1b), there was a significant $\sim 2$-fold increase in the percentage of myogenin-positive cells in $\mathrm{C} / \mathrm{EBP} \beta^{-/-}$ myoblast cultures as compared to WT (Fig. 1g, h) suggesting that $\mathrm{C} / \mathrm{EBP} \beta$-deficient cells are more predisposed to precociously differentiate under growth conditions, consistent with our previous findings [19].

To further investigate $\mathrm{C} / \mathrm{EBP} \beta$-dependent alteration in cell fate choices, we used single myofiber preparations isolated from the EDL muscles of wild-type (WT) and conditional null $\left(\mathrm{C} / \mathrm{EBP} \beta^{-/-}\right)$animals 1 week after daily tamoxifen ( $3 \mathrm{mg} / 40 \mathrm{~g}$ body weight for 5 days) injections to induce excision. $\mathrm{C} / \mathrm{EBP} \beta$ excision was confirmed by western blot of cell lysates from satellite cells isolated from the hind limb muscles (except EDL) of the tamoxifen-treated animals (Fig. 2a). Myofibers from the $\mathrm{WT}$ and $\mathrm{C} / \mathrm{EBP} \beta^{-/-}$mice were immunostained for Pax7 and MyoD and counterstained with DAPI to determine the number of self-renewing $\left(\operatorname{Pax} 7^{+} / \mathrm{MyoD}^{-}\right)$, activated $\left(\mathrm{Pax}^{+} / \mathrm{MyoD}^{+}\right)$, and differentiated $\left(\mathrm{Pax} 7^{-} / \mathrm{MyoD}^{+}\right) \mathrm{SCs}$ $72 \mathrm{~h}$ after isolation. The myofibers from the C/EBP $\beta^{-/-}$ animals had significantly fewer $\mathrm{Pax}^{+} / \mathrm{MyoD}^{-}$SCs (10.4\%) and more Pax7 ${ }^{-} / \mathrm{MyoD}^{+} \mathrm{SCs}(38.3 \%)$ compared to WT EDL myofibers (28.1 and $18.9 \%$, respectively) without affecting the proliferating $\mathrm{Pax}^{+} / \mathrm{MyoD}^{+}$population (Fig. 2b, c). Furthermore, when immunolabeled for Pax7 and myogenin, the myofibers from the C/EBP $\beta^{-1}$

animals had significantly more myogenin ${ }^{+}$cells (59\%) compared to the control EDL myofibers (34\%) (Fig. 2d, e). There were no changes in the number of satellite cells per cluster on $\mathrm{WT}$ and $\mathrm{C} / \mathrm{EBP} \beta^{-/-}$myofibers, confirming that loss of $\mathrm{C} / \mathrm{EBP} \beta$ does not inhibit SC activation (Fig. 2f). These results further demonstrate that $\mathrm{C} /$ $\mathrm{EBP} \beta$ promotes SC self-renewal and that loss of $\mathrm{C} / \mathrm{EBP} \beta$ in SCs leads to increased differentiation.

\section{$\mathrm{C} / \mathrm{EBP} \beta$ is required for the generation of reserve cells in vitro}

To examine the role of $\mathrm{C} / \mathrm{EBP} \beta$ in SC self-renewal during myogenic differentiation, $\mathrm{SC}$-derived myoblasts (wild-type and $\mathrm{C} / \mathrm{EBP}^{-/-}$) were cultured in high serum (GM) for $24 \mathrm{~h}$ and then switched to low serum (DM) for $48 \mathrm{~h}$ to induce differentiation. RT-qPCR analysis confirmed excision of $C e b p b$ in the myoblasts isolated from the $\mathrm{C} / \mathrm{EBP} \beta^{-/-}$ animals (Fig. 3a). Terminally differentiated cultures were fixed and stained for myosin heavy chain $(\mathrm{MyHC})$ and Pax7 expression to quantify myoblast fusion and reserve cell formation, respectively (Fig. 3b) [25, 28]. The differentiated $\mathrm{C} / \mathrm{EBP} \beta$-null cultures had fewer $\mathrm{Pax} 7^{+}$reserve cells (2.8\%) compared to the control cultures (8.2\%) (Fig. 3b, c) consistent with the reduction of $\mathrm{Pax}^{+} / \mathrm{MyoD}^{-}$cells observed in GM (Fig. 1d). Pax $7^{+}$reserve cells can be separated from myotubes by limited trypsinization and differentiated again to study self-renewal dynamics in a cell population $[25,28]$. To determine whether $\mathrm{C} / \mathrm{EBP} \beta^{-/-}$ 

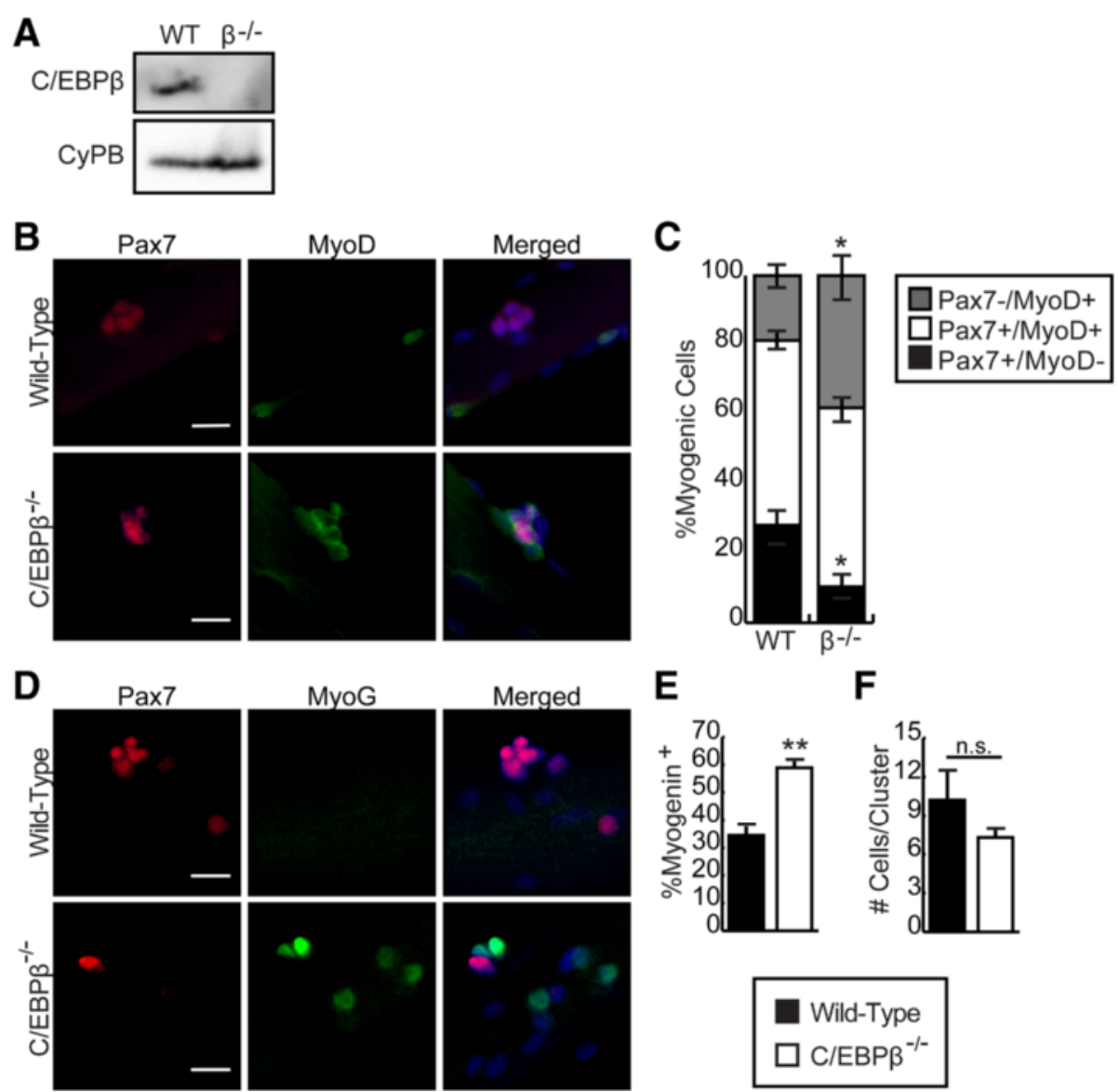

Fig. 2 LOSS of C/EBP $\beta$ inhibits satellite cell self-renewal and promotes differentiation. C/EBP $\beta^{\mathrm{f} / / 1 \mathrm{Pax}} 7^{+/+}$(wild-type) and conditional null C/EBP $\beta^{-/-} \mathrm{Pax} 7^{\mathrm{C}-}$ reER-/+ $\left(C / E_{B P} \beta^{-1-}\right)$ mice were injected daily with tamoxifen for 5 days. One week after the last injection, myofibers were isolated from the EDL of each mouse and cultured for 3 days in suspension before immunostaining. a Western analysis of C/EBP $\beta$ expression in SCs isolated from the hind limb of WT and C/EBP $\beta^{-1}$ mice injected with tamoxifen for 5 days. b Representative pictures of myofibers stained for Pax7 (red) and MyoD (green). Nuclei were counterstained with DAPI (blue). Scale bar, $20 \mu \mathrm{m}$. c Quantification of self-renewing (Pax $\left.7^{+} / \mathrm{MyoD}^{-}\right)$, proliferating $\left(\operatorname{Pax} 7^{+} / \mathrm{MyoD}^{+}\right)$, and differentiating $\left(\mathrm{Pax}^{-} / \mathrm{MyoD}^{+}\right.$) myoblasts on single myofibers ( $n=4$ mouse pairs). $\mathbf{d}$ Representative pictures of myofibers stained for Pax7 (red) and myogenin (green). Nuclei were counterstained with DAPI (blue). Scale bar, $20 \mu \mathrm{m}$. e Quantification of myogenin ${ }^{+}$cells as a percentage of total nuclei ( $n=3$ mouse pairs). f Total number of cells per cluster ( $n=3$ mouse pairs). For all panels, data is represented as mean \pm SEM $,{ }^{*} p<0.05,{ }^{* *} p<0.01$, n.s. not significant

reserve cells function normally, we collected reserve cells by limited trypsinization and, after expansion and equal plating, induced them to differentiate. After each round of differentiation, we counted the total number of reserve cells. After each passage, despite equal plating, there were fewer $\mathrm{C} / \mathrm{EBP}^{-/-}$reserve cells compared to wild-type cells (Fig. 3d). Further, after each round of differentiation, the number of reserve cells trended towards a decrease in the $\mathrm{C} / \mathrm{EBP} \beta^{-/-}$cultures but did not achieve statistical significance (Fig. 3d). These data suggests that C/EBP $\beta$ is required for maintenance of reserve cells in vitro.

$C / E B P \beta$ is required to restore the muscle satellite cell pool during regeneration

To confirm the reduced self-renewal potential of $\mathrm{C} / \mathrm{EBP} \beta^{-1}$ - satellite cells in vivo, an acute injury was induced by $\mathrm{BaCl}_{2}$ injection into the TA muscle of the $\mathrm{C} / \mathrm{EBP} \beta^{\mathrm{fl} / \mathrm{fl}} \mathrm{Pax} 7^{+/+}$ (wild-type) and conditional null C/EBP $\beta^{-/-} \operatorname{Pax}^{\mathrm{CreER}-/+}(\mathrm{C} /$ $\mathrm{EBP} \beta^{-/-}$) animals 1 week after tamoxifen administration ( $3 \mathrm{mg} / 40 \mathrm{~g}$ body weight daily for 5 days). The TA muscles were collected 0, 4, 7, and 42 dpi (Fig. 4a). Excision was confirmed by dual immunofluorescence staining of TA muscle sections for Pax7 and C/EBP $\beta$ (Fig. 4b, c). Immunostaining of injured TA muscle at 0,4 , and 7 dpi for Pax7 revealed that there were no changes in the number of Pax7 ${ }^{+}$cells in the $\mathrm{C} / \mathrm{EBP} \beta$-deficient muscle compared to the wild-type muscle (Fig. 4d, e), suggesting that $C / E B P \beta$-deficient myoblasts expand efficiently after muscle injury.

During postnatal regeneration, the size of the $\operatorname{Pax} 7^{+}$ satellite cell pool reaches homeostatic levels observed in the uninjured muscle 40 days after injury [29]. In the wild-type muscle, $\mathrm{Pax}^{+}$cell numbers returned to noninjured levels; however, there were significantly fewer $\mathrm{Pax}^{+}$cells in C/EBP $\beta$-null muscle (Fig. 4d, f). These 


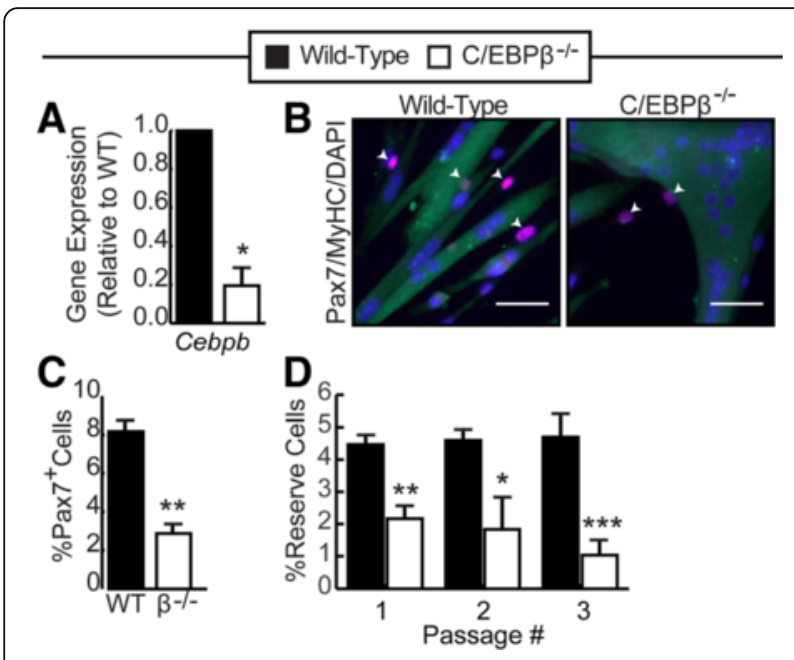

Fig. 3 Loss of C/EBP $\beta$ leads to a reduction in reserve cells in vitro. a RT-qPCR analysis of Cebpb expression in primary myoblasts isolated from C/EBP $\beta$ conditional knockout mice $\left(C / E B P \beta^{-/-}\right.$) or wild-type nonCre-expressing littermates subjected to in vitro $4^{\prime} \mathrm{OH}$-TAM treatment, cultured in GM, and plated and transferred to differentiation media for $48 \mathrm{~h}(n=3)$. b Representative pictures of cells stained for myosin heavy chain (MyHC; green) and Pax7 (red). Nuclei were counterstained with DAPI (blue). Scale bar, $50 \mu \mathrm{m}$. c Percentage of Pax $7^{+}$cells relative to total nuclei $(n=3)$. $\mathbf{d}$ Reserve cells were collected and counted following limited trypsinization after $48 \mathrm{~h}$ in differentiation media. After counting, the reserve cells were expanded, re-plated at equal densities, and induced to differentiate in low serum for another $48 \mathrm{~h}$. The number of reserve cells was counted after each round of differentiation and represented as a percentage of total nuclei $(n=3)$. Data is represented as mean $\pm \mathrm{SEM},{ }^{*} p<0.05,{ }^{* *} p<0.01,{ }^{* * *} p<0.001$

findings suggest that $C / E B P \beta$ is essential for directing cells towards self-renewal after injury.

\section{Loss of C/EBP $\beta$ expression cripples the long-term regenerative response}

As SC self-renewal is essential for efficient repair of tissue after injury, we examined muscle regeneration in wild-type and conditional null $\left(\mathrm{C} / \mathrm{EBP} \beta^{-/-}\right)$animals after two serial $\mathrm{BaCl}_{2}$ injuries separated by 21 days. TA muscles were collected 7 and 21 days after the second injury for analysis (Fig. 5a). One week following double injury (7 dpi), the TA muscle sections were stained for embryonic myosin heavy chain (eMyHC) to measure the size of newly regenerated fibers. Contrary to what was observed after a single injury [19], the average crosssectional area of $\mathrm{eMyHC}^{+}$fibers was significantly smaller in the $\mathrm{C} / \mathrm{EBP}^{-1-}$ muscle $(348 \mu \mathrm{m})$ compared to the wild-type muscle $(661 \mu \mathrm{m})$ (Fig. $5 \mathrm{~b}, \mathrm{c})$. There were also fewer Pax $7^{+}$cells in the C/EBP $\beta$-deficient muscle compared to the wild-type muscle (Fig. $5 \mathrm{~d}$ ). To confirm that the smaller fiber size in $\mathrm{C} / \mathrm{EBP} \beta$-null animals was not due to a delay in regeneration, we assessed the average cross-sectional area of fibers 21 days after secondary injury (21 dpi). Consistent with our 7 dpi findings, muscle fibers from the $\mathrm{C} / \mathrm{EBP} \beta^{-/-}$animals were smaller (1353 um) compared to the wild-type fibers $(1703 \mu \mathrm{m})$ (Fig. 5e, f) and the percentage of $\operatorname{Pax} 7^{+} \mathrm{SCs}$ remained lower in $\mathrm{C} / \mathrm{EBP} \beta$-deficient muscle (Fig. 5g). Taken together, these results strongly suggest that $\mathrm{C} / \mathrm{EBP} \beta$ is essential for $\mathrm{SC}$ self-renewal that is necessary for continual muscle regeneration.

\section{Activation of Notch signaling rescues self-renewal in C/EBP $\beta$-deficient myoblasts}

The Notch pathway is an established regulator of SC selfrenewal and homeostasis [30-33]; thus, we examined whether the expression of Notch1 intracellular domain (NICD) and Notch target genes (Hey1, Heyl) were disrupted in $\mathrm{C} / \mathrm{EBP}^{-/-}$myoblasts grown in GM. Western analysis revealed that the amount of the activated Notch (NICD) was decreased in the $\mathrm{C} / \mathrm{EBP} \beta^{-/-}$myoblasts as compared to the control myoblasts (Fig. 6a). Consistent with the reduced NICD, RT-qPCR revealed that the expression of the Notch target genes Heyl and Heyl was significantly downregulated in myoblasts deficient in $\mathrm{C} / \mathrm{EBP} \beta$ compared to wild-type myoblasts (Fig. 6b).

Since Notch signaling is reduced in $\mathrm{C} / \mathrm{EBP} \beta^{-/-}$myoblasts and Notch signaling is known to inhibit myogenic differentiation, we examined whether precocious differentiation in these cells could be rescued by NICD overexpression. Western analysis confirmed C/EBP $\beta$ excision and NICD overexpression in WT and C/EBP $\beta^{-/-}$myoblasts retrovirally transduced to express the NICD or with empty vector (pLP) (Fig. 6c). While the population of $\operatorname{Pax} 7^{+/} \mathrm{MyoD}^{-}$cells was significantly reduced with the loss of $\mathrm{C} / \mathrm{EBP} \beta$ expression, this population was restored to control levels with expression of the NICD (Fig. 6d). There were no significant changes in the $\operatorname{Pax} 7^{+} / \mathrm{MyoD}^{+}$ population, but NICD overexpression prevented the precocious differentiation $\left(\mathrm{Pax} 7^{-} / \mathrm{MyoD}^{+}\right)$observed in $\mathrm{C} /$ $\mathrm{EBP} \mathrm{\beta}^{-1-}$ myoblasts (Fig. 6e, f). Myogenin staining confirmed this finding (Fig. 6g), suggesting that the loss of self-renewal in $\mathrm{C} / \mathrm{EBP} \beta^{-/-}$myoblasts is due to decreased Notch signaling.

To determine how $\mathrm{C} / \mathrm{EBP} \beta$ regulates Notch signaling, we assessed Notch receptor expression (Notch1, Notch2, and Notch3) in wild-type and $\mathrm{C} / \mathrm{EBP} \beta^{-/-}$myoblasts, as well as, $\mathrm{C} 2 \mathrm{C} 12 \mathrm{~s}$ retrovirally transduced to overexpress $\mathrm{C} / \mathrm{EBP} \beta$ or with empty vector (pLXSN). RT-qPCR analysis revealed that both Notch 2 and Notch3 were significantly downregulated in $\mathrm{C} / \mathrm{EBP} \beta^{-/-}$myoblasts in the growth medium, while Notch1 expression was reduced but failed to reach statistical significance (Fig. 6h). In proliferating $\mathrm{C} 2 \mathrm{C} 12 \mathrm{~s}$ overexpressing Cebpb, Notch2 was the only Notch receptor significantly upregulated as compared to empty virus controls (Fig. 6i, j), suggesting that Notch 2 is regulated by $\mathrm{C} / \mathrm{EBP} \beta$ in myoblasts. We next examined whether $\mathrm{C} / \mathrm{EBP} \beta$ could occupy DNA 

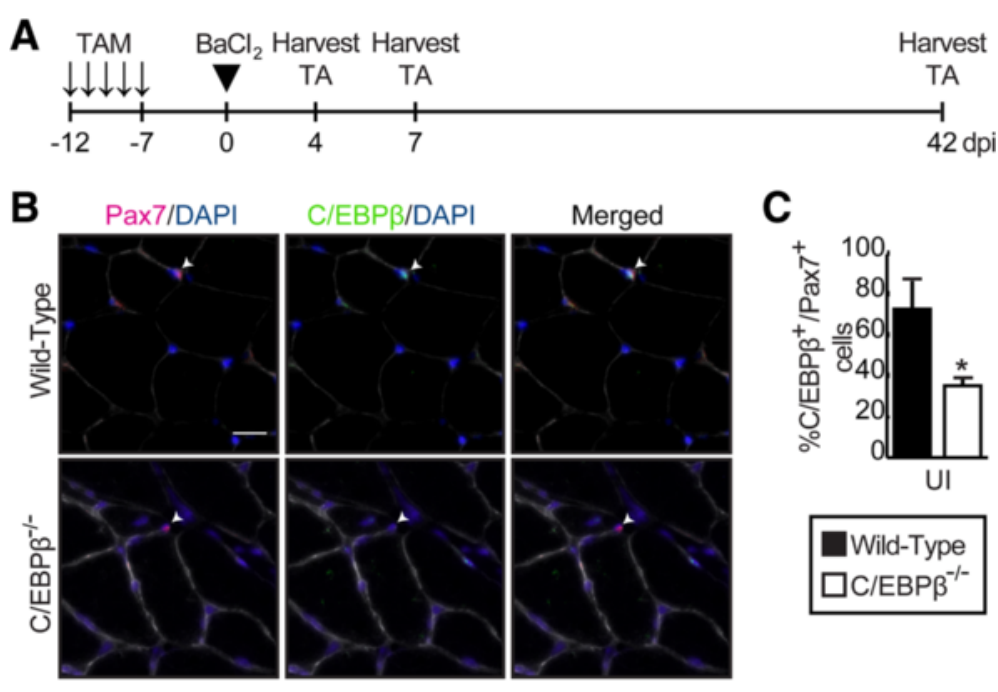

C/EBPB/DAPI

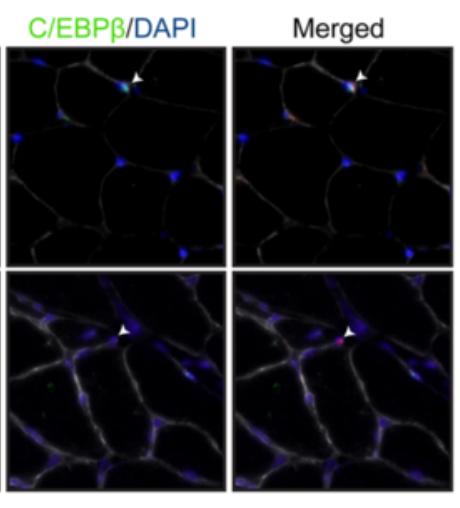

C
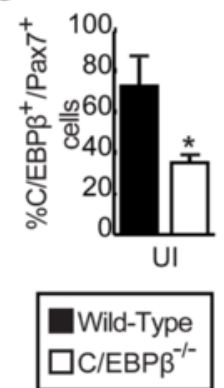

D

days post injury
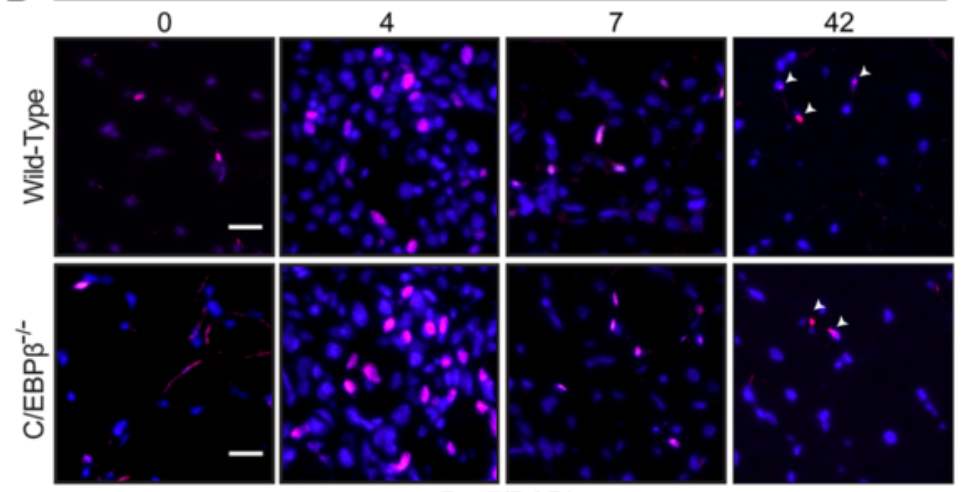

Pax7/DAPI

E
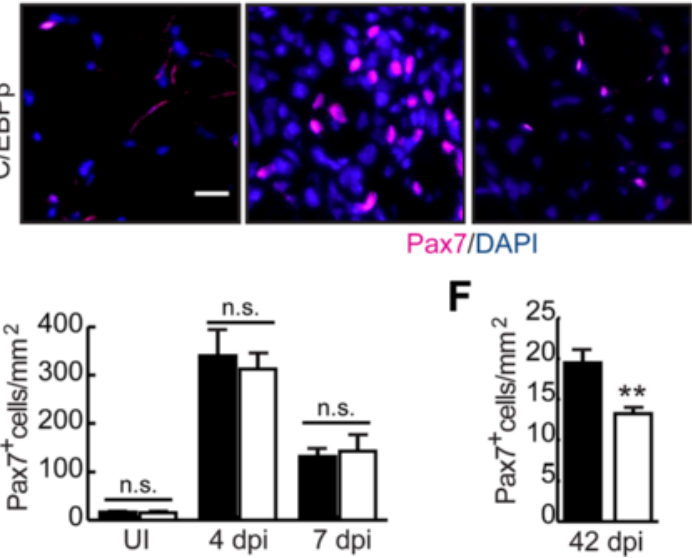

$\mathbf{F}$
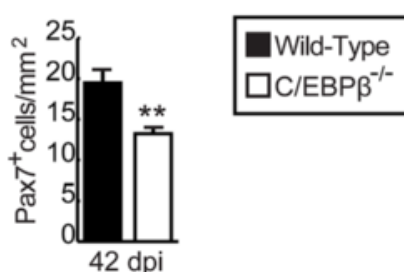

Fig. $4 \mathrm{C} / \mathrm{EBP} \beta$ is required for restoring the muscle stem cell pool after acute injury. a Experimental design. C/EBP $\beta^{\text {fl/fl }}$ Pax $7^{+/+}$(wild-type) and conditional null C/EBP $\beta^{-/-} \mathrm{Pax} 7^{\mathrm{CreER}-/+}\left(\mathrm{C} / \mathrm{EBP} \beta^{-/-}\right)$mice were injected daily with tamoxifen for 5 days. One week after the last injection, the left tibialis anterior (TA) muscle was injured by intramuscular injection of $50 \mu \mathrm{l}$ of $1.2 \% \mathrm{BaCl}_{2}$. The muscle was analyzed at $0,4,7$, and 42 days post injury (dpi). $\mathbf{b}$ Cross-sections of uninjured TA were immunostained for Pax7 (red), C/EBP 3 (green), and laminin (white). Nuclei were counterstained with DAPI (blue). Representative pictures are shown. Scale bar, $20 \mu \mathrm{m}$. c Excision efficiency in $\mathrm{Cre}^{+}$satellite cells represented by the percentage of C/EBP $\beta^{+}$nuclei among total Pax $7^{+}$cells in uninjured muscle $(n=3)$. d Cross-sections of injured TA $0,4,7$, and 42 dpi were immunostained for Pax7 (red) and counterstained with DAPI (blue). Representative pictures are shown. Scale bar, $20 \mu \mathrm{m}$. e Pax $7^{+}$cells per area $\left(\mathrm{mm}^{2}\right)$ at 0,4 , and $7 \mathrm{dpi}\left(n \geq 3\right.$ mouse pairs). $\mathbf{f}$ Pax $7^{+}$cells per area (mm $\left.{ }^{2}\right)$ at 42 dpi ( $n=4$ mouse pairs). For all panels, data is represented as mean \pm SEM, ${ }^{*} p<0.05,{ }^{*} p<0.01$, n.s. not significant

regulatory elements controlling Notch2 expression. Using available ChIP-seq data (GSE36024), we identified four peaks of C/EBP $\beta$ binding (E1-E4) of which E3 is a known Notch2 enhancer [34] and assessed C/EBP $\beta$ occupancy of these regions by chromatin immunoprecipitation (Fig. 6k). Under growth conditions, we found that $C / E B P \beta$ could occupy all of the regions identified by ChIP-seq, suggesting that CEBP $\beta$ can control entry into differentiation and self-renewal, at least in part, through regulation of Notch 2 expression and Notch activity.

\section{Discussion}

While most activated satellite cells will progress through myogenic differentiation, a small fraction escape, return to quiescence, and self-renew to maintain the muscle stem 

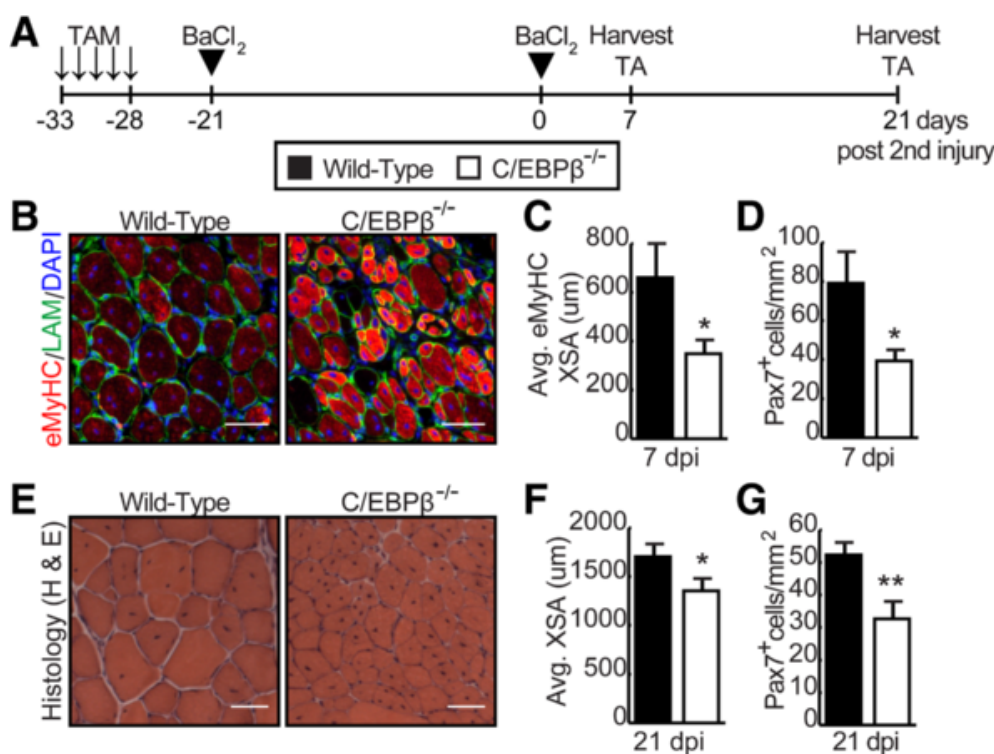

Fig. 5 Loss of C/EBP $\beta$ expression in satellite cells decreases regenerative capacity following serial injury. a Experimental design. $C / E B P \beta^{f / / f l} P a x 7^{+/+}$ (wild-type) and conditional null C/EBP $\beta^{-/-}$Pax $7^{\text {CreER-/+ }}\left(C / E B P ~ \beta^{-/}\right.$) mice were injected daily with tamoxifen for 5 days. One week after the last injection, the left tibialis anterior (TA) muscle was injured using $50 \mu \mathrm{l}$ of $1.2 \% \mathrm{BaCl}_{2}$ (1st injury). Twenty-one days after the initial injury, the same TA muscle was injured again using $50 \mu \mathrm{l}$ of $1.2 \% \mathrm{BaCl}_{2}$ (2nd injury). The muscle was analyzed at 7 and 21 days after the 2 nd injury (dpi). b Cross-sections of injured TA 7 dpi were stained with embryonic myosin heavy chain (eMyHC; red) and laminin (LAM; green). Nuclei were counterstained with DAPI (blue). Representative pictures are shown. Scale bar. $50 \mu \mathrm{m}$. c Average cross-sectional area of eMyHC fibers from TA sections stained as in $\mathbf{b}\left(n=5\right.$ mouse pairs). $\mathbf{d}$ Pax $7^{+}$nuclei were counted in 7 dpi muscle and represented as total Pax $7^{+}$cells per area $\left(\mathrm{mm}^{2}\right)(n=4$ mouse pairs). e Cross-sections of injured TA 21 dpi were stained for hematoxylin (nuclei; purple) and eosin (pink) (H\&E). Representative pictures are shown. Scale bar, $50 \mu \mathrm{m}$. f Average cross-sectional area of myofibers from TA sections stained as in $\mathbf{e}\left(n=6\right.$ mouse pairs). $\mathbf{g}$ Pax $7^{+}$nuclei were counted in 21 dpi muscle and represented as total Pax $7^{+}$cells per area $\left.(\mathrm{mm})^{2}\right)(n=3$ mouse pairs). Data is represented as mean $\pm \mathrm{SEM},{ }^{*} p<0.05,{ }^{* *} p<0.01$

cell population, marked by loss of MyoD expression. In addition to downregulation of MyoD expression, it is known that the SC population itself is heterogeneous and can undergo both asymmetrical and symmetrical divisions in the context of the niche, with asymmetric distribution of cellular proteins and chromatin templates which regulate the balance between SC maintenance and regenerative potential. Analysis of myogenic regulatory factor (Myf5 and $\mathrm{MyoD}$ ) expression in proliferating SCs revealed asymmetric expression of these factors in newly divided daughter cells [35-37]. These multiple mechanisms implicated in the maintenance of the skeletal muscle stem cell pool underlie the importance of these cells for muscle homeostasis. Too many cells destined towards repair results in rapid depletion of the SC compartment as observed with the loss of $C / E B P \beta$, while enhanced self-renewal restrains regeneration, with both disequilibria leading to muscle atrophy. Recently, loss of dystrophin expression in SCs in Duchenne muscular dystrophy was shown to reduce the available pool of SCs for repair, contributing to the pathogenesis of this disease [38].

While self-renewal is important for maintaining the precursor pool, the mechanisms by which some SCs evade differentiation remain poorly understood. In this study, we identify $C / E B P \beta$ as a novel regulator of $\mathrm{SC}$ self-renewal, demonstrating that in its absence, Pax7 ${ }^{+} / \mathrm{MyoD}^{-}$cells are generated in lesser number, resulting in a reduction of the satellite cell pool. While muscle in the conditional nulls repairs with greater efficiency after a single injury due to an increased propensity to differentiate [19], this repair results in a significant decrease in the SC population that cannot efficiently support repair after a second injury. However, using our conditional model, we observed a reduction in the satellite cell pool, rather than depletion, attributable to the incomplete excision of Cebpb and therefore the contribution of recombination escapers.

$\mathrm{C} / \mathrm{EBP} \beta$ is normally downregulated in early differentiation, a step that is required for full expression of $\mathrm{MyoD}$ and differentiation to occur [19]. Indeed, loss of C/EBP $\beta$ expression does not affect the progression towards the $\mathrm{Pax}^{+} / \mathrm{MyoD}^{+}$state. It remains unclear whether $\mathrm{C} / \mathrm{EBP} \beta$ is asymmetrically distributed in proliferating myoblasts or whether its expression is re-initialized in a small population of $\mathrm{Pax} 7^{+}$cells destined to self-renew. Indeed, while C/EBP $\beta$ expression does not appear to be required for Pax7 expression [19], it can force Pax7 to be expressed under differentiation conditions, and this mechanism could prevent myoblasts from completing myogenic differentiation. Many studies have demonstrated 

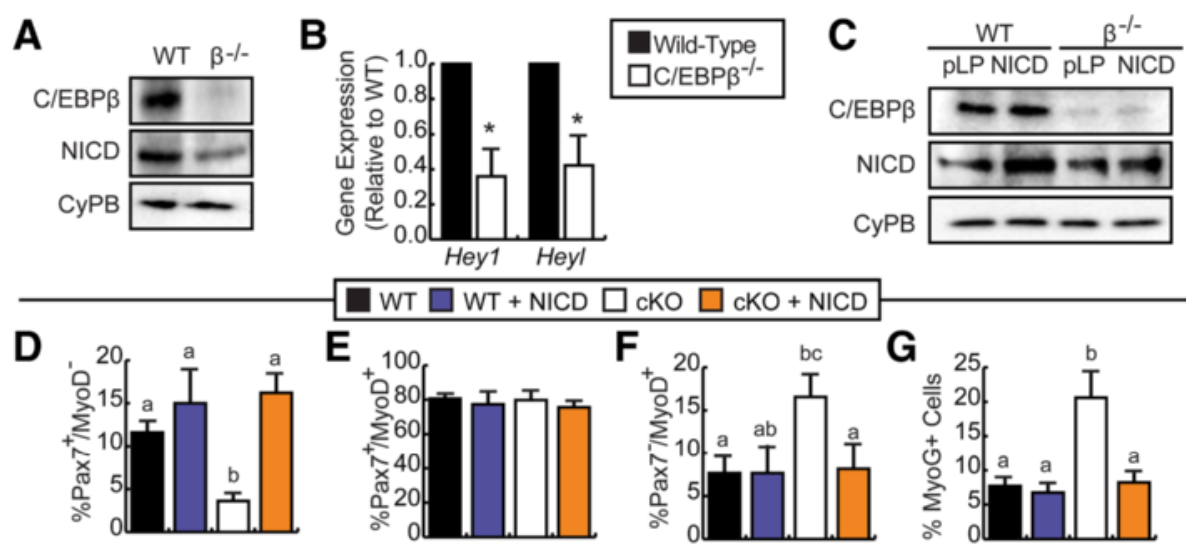

$\mathrm{pLXSN} \square \mathrm{C} / \mathrm{EBP} \beta$
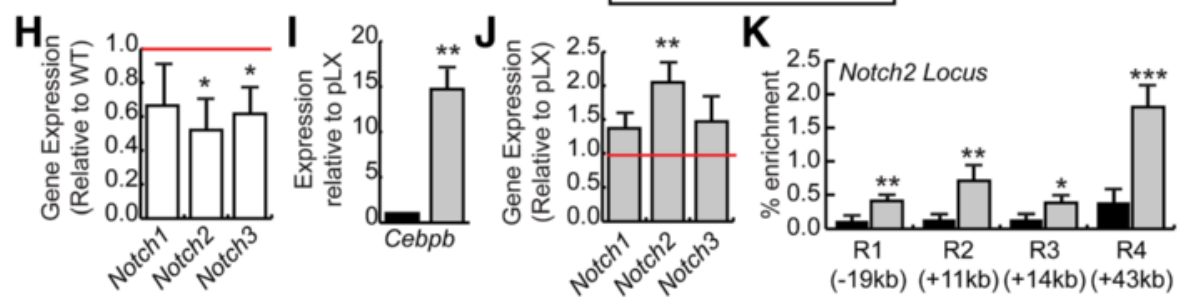

Fig. 6 Activation of Notch signaling rescues self-renewal in C/EBP $\beta$-deficient myoblasts. a Western analysis of C/EBP $\beta$ and NICD expression in primary myoblasts isolated from C/EBP $\beta$ conditional knockout mice $\left(\beta^{--}\right)$or wild-type non-Cre-expressing littermates (WT) subjected to in vitro $4^{\prime} \mathrm{OH}-\mathrm{TAM}$ treatment and cultured in growth medium (GM). Cyclophilin B (CyPB) is a loading control. b RT-qPCR analysis of Hey1 and Heyl expression in primary myoblasts isolated and cultured as in a $(n=5)$. c C/EBP $\beta$ and Notch1 intracellular domain (NICD) protein expression in wild-type (WT) and C/ $\mathrm{EBP}^{-1-}$ (cKO) primary myoblasts retrovirally transduced to express NICD or with empty virus (pLPCX; pLP) cultured in GM for $48 \mathrm{~h}(n=3)$. Percentage of $\mathbf{d}$ self-renewing $\left(\mathrm{Pax} 7^{+} / \mathrm{MyoD}^{-}\right)$, e proliferating $\left(\mathrm{Pax}^{+} / \mathrm{MyoD}^{+}\right)$, and $\mathbf{f}$ differentiating $\left(\mathrm{Pax}^{-} / \mathrm{MyoD}^{+}\right) \mathrm{WT}($ black bars), WT $+\mathrm{NICD}$ (blue bars), $\mathrm{C} / \mathrm{EBP} \beta^{-1-}$ (white bars), and C/EBP $\beta^{-1-}+\mathrm{NICD}$ (orange bars) myoblasts cultured as in $\mathbf{c}$ as determined by immunocytochemistry $(n=3)$. $\mathbf{g}$ Percentage of myogenin ${ }^{+}$cells relative to total nuclei $(n=3)$. h RT-qPCR analysis of Notch1, Notch2, and Notch3 expression in primary cells transduced to express C/EBP $\beta$ and cultured as in $\mathbf{a}$, shown relative to WT controls indicated by the red line $(n=5)$. $\mathbf{i}$ Cebpb and $\mathbf{j}$ Notch 1 , Notch2 and Notch3 expression in C2C12s retrovirally transduced to express C/EBP $\beta$ relative to empty vector controls (pLXSN, red line) cultured in growth medium for $24 \mathrm{~h}(n=4) . \mathbf{k}$ ChIP analysis of C/EBP $\beta$ occupancy at four regions (R1-R4) of the Notch2 locus in C2C12s retrovirally transduced to express C/EBP $\beta$ or empty vector (pLXSN) in GM. RT-qPCR data is shown as the percent enrichment relative to 10\% input used for immunoprecipitation for each condition $(n=4)$. Approximate region locations are relative to the transcriptional start site. Data is represented as mean $\pm \operatorname{SEM},{ }^{*} p<0.05,{ }^{* *} p<0.01$, ${ }^{* * *} p<0.001$. Means with different letters are significantly different

that adult skeletal muscles lacking Pax7-expressing satellite cells cannot regenerate $[2,39,40]$.

A number of signaling pathways have been implicated in SC self-renewal. Recent literature suggests that Notch signaling is crucial for SCs to self-renew and return to quiescence [30-33]. In adult muscle, the absence of Notch signaling induced spontaneous activation and differentiation of SCs which lead to a reduction in self-renewal and consequently impaired muscle regeneration [31, 32]. Furthermore, overexpression of Notch intracellular domain $\left(\mathrm{NICD}^{\mathrm{OE}}\right)$ upregulates Pax7, downregulates MyoD, and inhibits S-phase entry of primary myoblasts [33]. SC specific NICD ${ }^{\mathrm{OE}}$ also impaired regeneration of skeletal muscle [33] and loss of downstream Notch target genes Hesr1 (Hey1) and Hesr3 (HeyL) led to precocious differentiation, reduced SC self-renewal, and a reduced SC pool [30]. Interestingly, we show that the loss of C/EBP $\beta$ in SC-derived myoblasts results in a significant downregulation in genes involved in the Notch signaling pathway (Fig. 6) suggesting one possible mechanism by which $C / E B P \beta$ regulates SC self-renewal is through regulation of Notch. Indeed, changes in C/EBP $\beta$ expression induced changes in both Notch receptor expression and Notch activity as measured by Heyl and Heyl expression. While we identify Notch 2 as a target of C/EBP $\beta$ activity, we demonstrate that the Notch1 intracellular domain is also reduced, suggesting that $C / E B P \beta$ may regulate the Notch pathway at multiple levels. Recently, over-activation of Notch signaling was shown in progenitor cells in skeletal muscle of dystrophic mice [41]. We have shown that $C / E B P \beta$ expression persists in SCs of cachectic muscles and that these cells do not differentiate [42, 43]; thus, it is tempting to hypothesize that C/EBP $\beta$ may persist in SCs of dystrophic muscle, upregulating Notch expression and contributing to the dystrophic defect. Our findings provide a mechanism for $\mathrm{C} / \mathrm{EBP} \beta$-induced cell fate 
choices in myogenesis and identify $\mathrm{C} / \mathrm{EBP} \beta$ as a novel regulator of Notch signaling.

\section{Conclusions}

$\mathrm{C} / \mathrm{EBP} \beta$-deficient satellite cells are unable to efficiently self-renew after muscle injury, leading to a reduction in the SC pool and impaired regenerative capacity after serial injury. Taken together, our results establish $\mathrm{C} / \mathrm{EBP} \beta$ as a novel regulator of SC homeostasis that promotes differentiation at the expense of self-renewal. For example, while increased expression of $\mathrm{C} / \mathrm{EBP} \beta$ in cachectic muscle inhibits repair of wasting fibers, $\mathrm{C} / \mathrm{EBP} \beta$ protects the stem cells from apoptosis. The characterization of transcription factors controlling SC homeostasis provides important insights into the molecular mechanisms regulating skeletal muscle regeneration and further insight into the regulation of $C / E B P \beta$ function, and its biological role in the context of healthy and diseased muscle can fuel the development of novel therapeutic approaches for the treatment of muscle atrophies.

\section{Abbreviations \\ C/EBPB: CCAAT/enhancer binding protein beta; ChIP: Chromatin immunoprecipitation; DM: Differentiation media; dpi: Days post injury; EDL: Extensor digitorum longus; eMyHC: Embryonic myosin heavy chain; GM: Growth media; IHC: Immunohistochemistry; mRNA: Messenger ribonucleic acid; MyHC: Myosin heavy chain; MyoD: Myogenic differentiation factor 1; MyoG: Myogenin; NICD: Notch intracellular domain; Pax7: Paired box protein 7; PBS: Phosphate-buffered saline; PFA: Paraformaldehyde; RT- QPCR: Real-time quantitative polymerase chain reaction; SC: Satellite cell; TA: Tibialis anterior; WT: Wild-type}

\section{Acknowledgements}

NLT was supported by an Ontario Graduate Scholarship. HA is supported by a graduate scholarship from King Saud University, Saudi Arabia. FM was supported by a scholarship from the fonds de la recherche en santé du Québec (FRSQ). The Pax7-CreER mouse was kindly provided by Dr. Charles Keller at the Oregon Health \& Science University (Portland, OR), and the $\mathrm{Cebpb}^{\text {ff/fl }}$ mouse was a kind gift from Dr. Esta Sterneck at the Center for Cancer Research at the National Institutes of Health. The authors wish to thank Jemima Yeoman for the pLPCX-NICD construct.

\section{Funding}

This work was supported by grants from the Canadian Institutes of Health Research (CIHR) (grant number 115029) to NWB.

\section{Authors' contributions}

NLT contributed to the conception and design, the collection, assembly, the analysis and interpretation of the data, the manuscript writing, and the final approval of the manuscript. HA and FM contributed to the conception and design, the collection, assembly, the analysis and interpretation of the data, and the final approval of the manuscript. DF contributed to the collection and assembly of the data, the data analysis and interpretation, and the final approval of manuscript. NWB contributed to the conception and design, the financial support, the data analysis and interpretation, the manuscript writing, and the final approval of manuscript.

\section{Competing interests}

The authors declare that they have no competing interests.

\section{Ethics approval}

The animal experiments were approved by the University of Ottawa's Animal Care Committee (protocols CMM-2165-R1-A1, CMM-2166-R1) respecting the standards for ethical use of animals stipulated by the Canadian Council on Animal Care.

\section{Author details}

Graduate Program in Cellular and Molecular Medicine, Faculty of Medicine, University of Ottawa, 451 Smyth Road, Ottawa, Ontario K1H 8M5, Canada. 2Department of Cellular and Molecular Medicine, Faculty of Medicine, University of Ottawa, 451 Smyth Road, Ottawa, Ontario K1H 8M5, Canada.

Received: 13 July 2016 Accepted: 8 November 2016

Published online: 07 December 2016

\section{References}

1. Collins CA, Olsen I, Zammit PS, Heslop L, Petrie A, Partridge TA, Morgan JE. Stem cell function, self-renewal, and behavioral heterogeneity of cells from the adult muscle satellite cell niche. Cell. 2005;122:289-301.

2. Sambasivan R, Yao R, Kissenpfennig A, Van Wittenberghe L, Paldi A, GayraudMorel B, Guenou H, Malissen B, Tajbakhsh S, Galy A. Pax7-expressing satellite cells are indispensable for adult skeletal muscle regeneration. Development. 2011:138:3647-56.

3. Seale P, Sabourin LA, Girgis-Gabardo A, Mansouri A, Gruss P, Rudnicki MA. Pax7 is required for the specification of myogenic satellite cells. Cell. 2000; 102:777-86.

4. Fukada S, Uezumi A, Ikemoto M, Masuda S, Segawa M, Tanimura N, Yamamoto $\mathrm{H}$, Miyagoe-Suzuki Y, Takeda S. Molecular signature of quiescent satellite cells in adult skeletal muscle. Stem Cells. 2007;25:2448-59.

5. Kuang S, Rudnicki MA. The emerging biology of satellite cells and their therapeutic potential. Trends Mol Med. 2008;14:82-91.

6. Gnocchi VF, White RB, Ono Y, Ellis JA, Zammit PS. Further characterisation of the molecular signature of quiescent and activated mouse muscle satellite cells. PLoS One. 2009:4:e5205.

7. Yablonka-Reuveni Z, Rivera A. Temporal expression of regulatory and structural muscle proteins during myogenesis of satellite cells on isolated adult rat fibers. Dev Biol. 1994;164:588-603.

8. Chen JC, Goldhamer DJ. Transcriptional mechanisms regulating MyoD expression in the mouse. Cell Tissue Res. 1999;296:213-9.

9. Zammit PS, Relaix F, Nagata Y, Ruiz AP, Collins CA, Partridge TA, Beauchamp JR. Pax7 and myogenic progression in skeletal muscle satellite cells. J Cell Sci. 2006;119:1824-32

10. Hasty P, Bradley A, Morris JH, Edmondson DG, Venuti JM, Olson EN, Klein WH. Muscle deficiency and neonatal death in mice with a targeted mutation in the myogenin gene. Nature. 1993;364:501-6.

11. Zammit PS, Golding JP, Nagata Y, Hudon V, Partridge TA, Beauchamp JR. Muscle satellite cells adopt divergent fates: a mechanism for self-renewal? J Cell Biol. 2004;166:347-57.

12. Tedesco FS, Dellavalle A, Diaz-manera J, Messina G, Cossu G. Review series repairing skeletal muscle: regenerative potential of skeletal muscle stem cells. J Clin Invest. 2010;120:11-9.

13. Motohashi N, Asakura A. Muscle satellite cell heterogeneity and self-renewal. Front Cell Dev Biol. 2014;2:1-11.

14. Halevy O, Piestun $Y$, Allouh MZ, Rosser BWC, Rinkevich $Y$, Reshef R, Rozenboim I, Wleklinski-Lee M, Yablonka-Reuveni Z. Pattern of Pax7 expression during myogenesis in the posthatch chicken establishes a model for satellite cell differentiation and renewal. Dev Dyn. 2004;231:489-502.

15. Olguin HC, Olwin BB. Pax-7 up-regulation inhibits myogenesis and cell cycle progression in satellite cells: a potential mechanism for self-renewal. Dev Biol. 2004;275:375-88.

16. Sacco A, Doyonnas R, Kraft P, Vitorovic S, Blau HM. Self-renewal and expansion of single transplanted muscle stem cells. Nature. 2008;456:502-6.

17. Montarras D, Morgan J, Collins C, Relaix F, Zaffran S, Cumano A, Partridge T, Buckingham M. Direct isolation of satellite cells for skeletal muscle regeneration. Science (80-). 2005;309:2064-7.

18. Ramji D, Foka P. CCAAT/enhancer-binding proteins : structure, function and regulation. Biochem J. 2002;365:561-75.

19. Marchildon F, Lala N, Li G, St-Louis C, Lamothe D, Keller C, Wiper-Bergeron N. CCAAT/enhancer binding protein beta is expressed in satellite cells and controls myogenesis. Stem Cells. 2012;30:2619-30.

20. Fu D, Lala-Tabbert N, Lee H, Wiper-Bergeron N. Mdm2 promotes myogenesis through the ubiquitination and degradation of CCAAT/ enhancer binding protein $\beta$. J Biol Chem. 2015;290:10200-10207.

21. Lamarche É, Lala-Tabbert N, Gunanayagam A, St-Louis C, Wiper-Bergeron N. Retinoic acid promotes myogenesis in myoblasts by antagonizing transforming growth factor-beta signaling via C/EBP 3 . Skelet Muscle. 2015;5:8. 
22. Sterneck E, Zhu S, Ramirez A, Jorcano J, Smart R. Conditional ablation of C/EBP $\beta$ demonstrates its keratinocyte-specific requirement for cell survival and mouse skin tumorigenesis. Oncogene. 2006;25:1272-6.

23. Nishijo K, Hosoyama T, Bjornson CRR, Schaffer BS, Prajapati SI, Bahadur AN, Hansen MS, Blandford MC, McCleish AT, Rubin BP, Epstein JA, Rando TA, Capecchi MR, Keller C. Biomarker system for studying muscle, stem cells, and cancer in vivo. FASEB J. 2009;23:2681-90.

24. Motohashi N, Asakura Y, Asakura A. Isolation, Culture, and Transplantation of Muscle Satellite Cells. J Vis Exp. 2014;(86):e50846. doi:10.3791/50846.

25. Kitzmann M, Carnac G, Vandromme M, Primig M, Lamb NJ, Fernandez A. The muscle regulatory factors MyoD and myf-5 undergo distinct cell cyclespecific expression in muscle cells. J Cell Biol. 1998;142:1447-59.

26. Pasut A, Jones AE, Rudnicki MA. Isolation and Culture of Individual Myofibers and their Satellite Cells from Adult Skeletal Muscle. J Vis Exp. 2013:(73):e50074. doi:10.3791/50074.

27. Wiper-Bergeron N, Wu D, Pope L, Schild-Poulter C, Haché RJG. Stimulation of preadipocyte differentiation by steroid through targeting of an HDAC1 complex. EMBO J. 2003;22:2135-45.

28. Yoshida N, Yoshida S, Koishi K, Masuda K, Nabeshima Y. Cell heterogeneity upon myogenic differentiation: down-regulation of MyoD and Myf-5 generates "reserve cells". J Cell Sci. 1998;111:769-79.

29. Shea KL, Xiang W, LaPorta VS, Licht JD, Keller C, Basson MA, Brack AS. Sprouty 1 regulates reversible quiescence of a self-renewing adult muscle stem cell pool during regeneration. Cell Stem Cell. 2010;6:117-29.

30. Fukada S, Yamaguchi M, Kokubo H, Ogawa R, Uezumi A, Yoneda T, Matev MM, Motohashi N, Ito T, Zolkiewska A, Johnson RL, Saga Y, Miyagoe-Suzuki Y, Tsujikawa K, Takeda S, Yamamoto H. Hesr1 and Hesr3 are essential to generate undifferentiated quiescent satellite cells and to maintain satellite cell numbers. Development. 2011;138:4609-19.

31. Mourikis P, Sambasivan R, Castel D, Rocheteau P, Bizzarro V, Tajbakhsh S. A critical requirement for Notch signaling in maintenance of the quiescent skeletal muscle stem cell state. Stem Cells. 2012;30:243-52.

32. Bjornson CRR, Cheung TH, Liu L, Tripathi PV, Steeper KM, Rando TA. Notch signaling is necessary to maintain quiescence in adult muscle stem cells. Stem Cells. 2012:30:232-42.

33. Wen Y, Bi P, Liu W, Asakura A, Keller C, Kuang S. Constitutive Notch activation upregulates Pax7 and promotes the self-renewal of skeletal muscle satellite cells. Mol Cell Biol. 2012;32:2300-11.

34. Chalamalasetty RB, Dunty WC, Biris KK, Ajima R, lacovino M, Beisaw A, Feigenbaum L, Chapman DL, Yoon JK, Kyba M, Yamaguchi TP. The Wnt3a/ $\beta$-catenin target gene Mesogenin 1 controls the segmentation clock by activating a Notch signalling program. Nat Commun. 2011;2:390.

35. Kuang S, Kuroda K, Le Grand F, Rudnicki MA. Asymmetric self-renewal and commitment of satellite stem cells in muscle. Cell. 2007;129:999-1010.

36. Troy A, Cadwallader AB, Fedorov Y, Tyner K, Tanaka KK, Olwin BB. Coordination of satellite cell activation and self-renewal by Par-complexdependent asymmetric activation of p38a/ß MAPK. Cell Stem Cell. 2012;11: 541-53.

37. Liu W, Wen Y, Bi P, Lai X, Liu XS, Liu X, Kuang S. Hypoxia promotes satellite cell self-renewal and enhances the efficiency of myoblast transplantation. Development. 2012;139:2857-65.

38. Dumont NA, Wang YX, von Maltzahn J, Pasut A, Bentzinger CF, Brun CE, Rudnicki MA. Dystrophin expression in muscle stem cells regulates their polarity and asymmetric division. Nat Med. 2015;21:1455-63.

39. Lepper C, Partridge TA, Fan CM. An absolute requirement for Pax7-positive satellite cells in acute injury-induced skeletal muscle regeneration. Development. 2011;138:3639-46.

40. Murphy MM, Lawson JA, Mathew SJ, Hutcheson DA, Kardon G. Satellite cells, connective tissue fibroblasts and their interactions are crucial for muscle regeneration. Development. 2011;138:3625-37.

41. Mu X, Tang Y, Lu A, Takayama K, Usas A, Wang B, Weiss K, Huard J. The role of Notch signaling in muscle progenitor cell depletion and the rapid onset of histopathology in muscular dystrophy. Hum Mol Genet. 2015;24:2923-37.

42. Marchildon F, Lamarche E, Lala-Tabbert N, St-Louis C, Wiper-Bergeron N. Expression of CCAAT/enhancer binding protein beta in muscle satellite cells inhibits myogenesis in cancer cachexia. PLoS One. 2015;10:1-16.

43. Marchildon F, Fu D, Lala-Tabbert N, Wiper-Bergeron N. CCAAT/enhancer binding protein beta protects muscle satellite cells from apoptosis after injury and in cancer cachexia. Cell Death Dis. 2016;7:e2109.

\section{Submit your next manuscript to BioMed Central and we will help you at every step:}

- We accept pre-submission inquiries

- Our selector tool helps you to find the most relevant journal

- We provide round the clock customer support

- Convenient online submission

- Thorough peer review

- Inclusion in PubMed and all major indexing services

- Maximum visibility for your research

Submit your manuscript at www.biomedcentral.com/submit
Biomed Central 